150

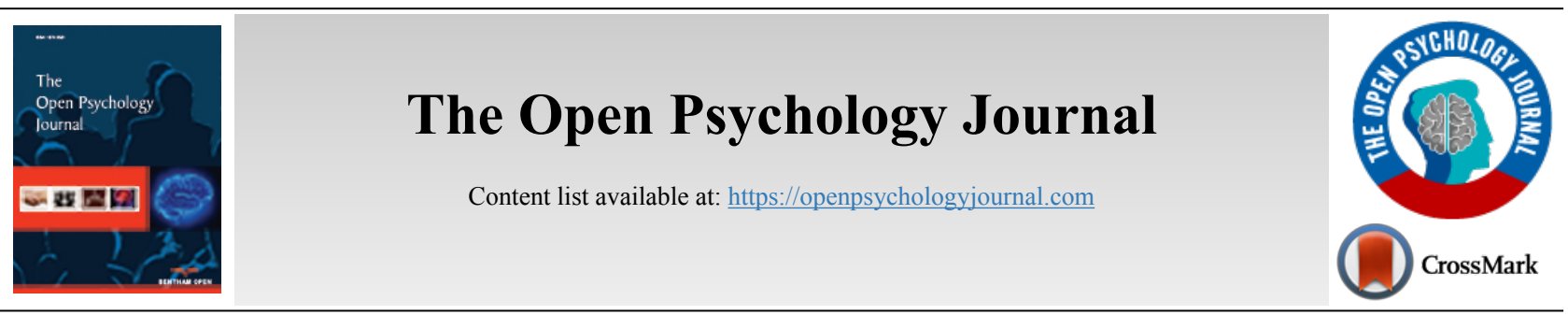

RESEARCH ARTICLE

\title{
Value Orientations of Modern Kazakhstanis
}

Elnur Adilova ${ }^{1}$, Olga Aimaganbetova ${ }^{1, *}$, Laura Kassymova ${ }^{2}, Z$ Zuhra Sadvakassova ${ }^{1}$, Madina Ryskulova ${ }^{3}$ and Tolkyn Sagnayeva ${ }^{4}$

${ }^{\prime}$ Department of General and Applied Psychology, Al-Farabi Kazakh National University, Almaty, Republic of Kazakhstan

${ }^{2}$ Centre for Cross Cultural Research, University of Guelph, Guelph, Ontario, Canada

${ }^{3}$ Department of Psychology, L.N. Gumilyov Eurasian National University, Nur-Sultan, Kazakhstan

${ }^{4}$ Department of Psychology, Turan University, Almaty, Republic of Kazakhstan

\section{Abstract: \\ Background \& Objective:}

Values are a good indicator for tracking social and individual changes due to historical, social and personal events. Therefore, it is important to explore the values of modern Kazakhstanis and determine the dialectical relationship of integrity, stability, and dynamics in the invariance of the system of value orientations during socio-economic, political, religious, aesthetic, and cultural-historical changes in post-Soviet society. Comprehending the problem of transformation and transmission of values will allow us to consider the underlying psychological processes influencing the formation of personal values. This research aimed to study the value orientations of modern Kazakhstanis of the post-Soviet period in the context of gender and age factors.

Methods:

The study involved 305 respondents, of which 192 were women and 113 were men, while the age of 202 respondents ranged from 18 to 25 years, and that of 103 respondents ranged from 50 to 65 years. For the study of value orientations, the "Modified Questionnaire of Values" (PVQ-R) by S. Schwartz was used.

Results:

In the system of value orientations of Kazakhstanis, an internal conflict can be traced between personal and social focus, and between selfdetermination and self-affirmation. Two generations are differentiated by the following values: the value of Achievement, Social complexity, and Control of fate. The two sexes are differentiated by values such as Social cynicism, Control of fate, Stimulation, Personal Security, Modesty, Universalism-Tolerance, Benevolence-Care and Benevolence-Sense of duty.

\section{Conclusion:}

Despite the late deep transformations of Kazakhstani society, the value orientations of modern Kazakhstanis tend to preserve the basic value component, which is a mechanism of transferring the stable elements of the value system of a highly collective culture from generation to generation. The value orientations of Kazakhstani people of both young and older generations are realized through mechanisms of growth and development, and self-defense.

Keywords: Values, Value orientations, Transformation, Post-Soviet society, Modern Kazakhstani youth, Age, Gender characteristics.

Article History Received: July 12, 2020

Revised: December 28, 2020 Accepted: March 7, 2021

\section{INTRODUCTION}

Modern Kazakhstan is a young sovereign state in Central Asia that formed after the collapse of the Soviet empire. Today it is a modern state located between Russia, China and countries of Central Asia, where 130 nationalities live, all

\footnotetext{
* Address correspondence to this author at the Department of General and Applied Psychology, Al-Farabi Kazakh National University, Almaty, Republic of Kazakhstan; E-mail:o.aimaganbetova@gmail.com
}

major world confessions are represented, and Asian and European cultures are harmoniously blended. This is the only state in the post-Soviet space on the territory of which there were no interethnic and interconfessional conflicts. Kazakhstani model of economic development is aimed primarily at strengthening interethnic acceptableness and unity, and political stability.

With rich reserves of oil, gas, rare and colored metals and 
uranium in the depths, the country has a developed oil and gas and metallurgical industry, developed agricultural industry, and an education system that has switched to European standards. In order to train the national elite, more than 200 young people get the opportunity to study for free in the best universities of the world annually, including the USA and England.

At present, there is an increase in the number of the indigenous population, which lost up to $40 \%$ of its numbers during the Holodomor organized by communists in the 1930s, and moreover, underwent intensified assimilation and Russification.

Only after the collapse of the Soviet Union and its gaining independence, the Kazakh language received the status of the state language, and the restoration of national customs and traditions, constituting the national heritage and values that were created by the people during the centuries, began.

Gaining independence and a change in the political regime influenced socio-psychological phenomena, including values. Currently, there is a tendency to reassess value orientations corresponding to the new social reality. Social and political factors that caused changes in the structure of value orientations of Kazakhstanis, first of all, affected modern youth. Kazakhstani youth is an important object of sociopsychological study of the dynamics of the development of post-Soviet society, since it represents a significant part of the society, expressing the main trends in its development and, at the same time, is the source and carrier of the most acute social contradictions and problems. Young people are forced to adapt not so much to an external, objectively existing environment as to the social space that they create themselves. The process and result of the inclusion of man into society are performed due to the assimilation and reproduction of the value system. In the process of formation of the personality of a young man, a certain system of value orientations plays a critical role, which is formed under the influence of values that prevail in society and the immediate social environment surrounding the person, though it is not strictly predetermined by them. The personality "assimilates" selectively the values offered by the society. The system of value orientations is not predetermined once and for all; with changes in the living conditions and the personality itself, new values appear, and sometimes their full or partial revaluation occurs [1].

Value orientations are elements of the personality structure that characterize the content side of the orientation of the personality. The system of value orientations acts as a "minimized" program of life and serves as the basis for the implementation of a certain personality model; the area where the social values pass into the person and the personal values become social values. Value is one of the main mechanisms of interaction between the individual and society and the individual and culture [2]. The mental health and spiritual wellbeing of a person depend on how well-formed the personality's value system is. In modern psychology, more and more attention is paid to considering a person as a subject of life changes, the importance of a subjective understanding of the world is recognized, and thus the worth of the value aspects of human life is increasing [3]. All this indicates the actualization of scientific interest in the problems of studying value orientations in revealing the psychological aspects of the formation, development, transformation, refraction, and transmission of value orientations of modern Kazakhstanis. Values are a good indicator for tracking the progress of social and individual changes as a result of historical, social, and personal events. Therefore, it is important to explore the values of modern Kazakhstanis and determine the dialectical connection of integrity, stability, and dynamics in the invariance of the system of value orientations during socioeconomic, political, religious, aesthetic, and cultural-historical changes in post-Soviet society. Understanding the problem of transformation and transmission of values will allow us to consider and understand the underlying psychological processes influencing the formation of personal values.

Thus, there are contradictions between changing social and political conditions that influence the value orientations of modern Kazakhstanis and the understudied features of value orientations in psychological science, taking into account age and gender factors. In this regard, the importance of studies that are aimed at analyzing and studying the problems of value orientations of modern Kazakhstanis is growing.

The purpose of the study is to investigate the value orientations of modern Kazakhstanis of the post-Soviet period in the context of gender and age factors. When determining the hypothesis of the study, we proceeded from the assumption that despite the deep transformations of Kazakhstani society, the value orientations of modern Kazakhstanis tend to preserve the basic value component, which is a mechanism for transferring stable elements of a value system from generation to generation. Value orientations are of common nature in different generations.

The novelty of this study is determined by the fact that for the first time in Kazakhstani psychology, the software "Qualtrics" was used to study the system of value orientations in the online mode. Also, for the first time, a modification of the value questionnaire (PVQ-R) by Sh. Schwartz in the Kazakh and Russian versions for the Kazakh sample was made. In addition, this method has been translated into the Kazakh language using the double translation technique of O. Werner and D. Campbell for the first time.

\section{LITERATURE REVIEW}

While developing a socio-psychological approach to the study of value orientations, we relied on concepts developed by foreign, Soviet (Russian) and Kazakhstani scientists.

In the opinion of A. Maslow, the system of value orientations of the personality acts as the main regulator of personality activity and the direction of its development [4]. V. Frankl understood by the values of personality the so-called "universals of meaning", that is, the meanings inherent in most members of society, all of humanity throughout its historical development. The subjective significance of value, according to V. Frankl, should be accompanied by acceptance of responsibility for its implementation [5]. A great contribution to the study of values was made by M. Rokich, who proposed a typology of values on motivational-target and procedural components. The motivational-target component is the basis of terminal values, which summarize the most important ideals, 
goals, life-meaning orientations of people - such as the value of human life, family, interpersonal relationships, labor, selfrealization, etc. Terminal values (values-goals), in turn, are divided into concrete and abstract values and the values of professional self-realization and personal life. Instrumental values are means of activity and include ethical values, communication values, business values; individualistic, conformist, and altruistic values; values of self-affirmation; and values of acceptance of other people. Instrumental values reflect the means of achieving goals that are encouraged in a given society. On the one hand, these are moral and ethical norms of behavior, while on the other hand, these are the qualities and abilities of people [6]. From the point of view of the modern Western values researcher Y. Musek, value orientations are forms of functioning of values at the individual level, that is, personal values. He proposed to consider values "as generalized and relatively consistent ideas about goals and events highly significant for us" [7]. Closest to this approach is the modern concept of values proposed by S. Schwartz, who proposed to consider the totality of values as a motivational continuum, where the differences between the values are more continuous than discrete [8]. According to Schwartz's theory, cross-cultural value space is defined by two axes (openness to change - conservatism, altruism - egoism) and has a circular structure. In the space of these axes are 10 basic value orientations [9]. B. Schleder, based on the concept of $\mathrm{H}$. Klades, distinguishing, on the one hand, the values of public duty and recognition (discipline, order, and obedience), while on the other hand, the values of self-realization (creativity, selfaffirmation, and freedom), developed a popular method for diagnosing the structure of value orientations of personality [10].

According to the Russian psychologist D.A. Leontiyev, personal values are an "ideal model of the due" for determining the direction of the desired transformation of reality [11]. Being the central structure of the semantic sphere of the personality, personal values determine the general approach of the individual to the world, to himself, give meaning and direction to his life, and are the main sources of the processes of meaning formation and life meanings [12]. B.G. Ananyev suggested considering values as one of the central links in a comprehensive study of the personality and patterns of its development. Based on the social status of the individual, systems of its social roles and value orientations are formed. The status, roles and value orientations, forming the primary class of personal properties, determine the characteristics of the structure and motivation of behavior, and, in interaction with them, the nature and inclinations of a person [13]. Modern Russian psychologist M.A. Khachatryan proposed to consider values as constructs of a certain type, which are formed in the context of the social interaction of the subject. He believes that the main function of values is the categorization and construction of a picture of the world, organizing human behavior in the framework of a consciously chosen direction of life [14].

The problem of value orientations has been highlighted in the research of Kazakhstani scientists in recent years. S.I. Bogdan, studying the psychological factors of the formation of value orientations of the personality on the example of student youth in Kazakhstan, came to the conclusion that the integration of students' personality in the university environment reveals the assimilation of behavioral manifestations in which there is a rejection of previous values and the system of values of the new environment is adopted [15]. Research by D.T. Ikhsanova and A.B. Aimaganbetov showed that modern Kazakhstani youth during the process of socialization is forced to rely not on the experience of previous generations, but on new social experience. As the most important value, they noted: "the ability to find oneself in life" [16]. L. Kasym conducted a study of value orientations using the author's modification of the Schwartz values questionnaire and the Social Axioms questionnaire by M. Bond and K. Leung for the Kazakhstan sample. The study revealed the presence of features in the group ideas of students about the system of significant and leading values that determine the ethnic identity of the Kazakh and Russian ethnic groups [17]. An analysis of the factor structures of representatives of the Kazakh and Russian samples showed that in the sample of Kazakhs, the orientation to the family as a terminal value was revealed. The sample of Russian students was distinguished by an active desire for self-realization, self-sufficiency, confidence in their abilities and capabilities [18].

Thus, the basis of our study of the problems of value orientations was the general scientific principles of the sociocultural determination of mental processes and phenomena as a general paradigm of modern psychology. This is the culturalhistorical theory of L.S. Vygotsky [19] and M. Cole [20]. Consequently, interdisciplinary synthesis was chosen as a general theoretical position during the understanding and study of value orientations.

\section{METHODOLOGY}

\subsection{Sampling}

The experimental work was carried out according to the guidelines of Al-Farabi Kazakh National University, Department of General and Applied Psychology.

The study involved 305 respondents, of whom 192 were women and 113 were men living in Almaty and Karaganda regions. To study the peculiarities of transferring the value system from the older generation to the younger, two samples were formed: one sample consisted of young people aged 18 to 25 years (202 respondents), and the second sample consisted of mature respondents aged 50 to 65 years (103 respondents). By ethnic background, these are representatives of the Kazakh and Russian nationalities, which represent the majority of the population of the republic.

Criteria for exclusion of respondents from the study:

1. Respondents aged 26 to 49 years.

2. Respondents who did not fully answer the questionnaires, missing $2-3 \%$ of the questions.

The model for selecting respondents was probabilistic in nature: any student living in Almaty and Karaganda regions could take part in the study. The choice of youth as a target audience is because the value orientations of students as the most active and dynamic part of society are the first to undergo 
those changes in society. Nevertheless, they are not strictly predetermined by them, since this process is influenced not only by social factors and the environment, but, above all, also by the characteristics of the personality itself and its sociopsychological characteristics. Consequently, the system of value orientations is not once and for all determined; the values offered by society are assimilated selectively by students with changes in living conditions, the personality itself, new values appear, and sometimes they are fully or partially re-evaluated. Therefore, in general, students' age is a decisive period in the development of value orientations, their strengthening, and consolidation.

\subsection{Measures}

S. Schwartz's "Modified Questionnaire of Values" (PVQ$\mathrm{R}$ ) was used to conduct a study of value orientations based on the fact that all individual values are based on the basic conditions of human existence (one or more): a) the needs of the body; b) the desire for social interactions; and c) the need for belonging to a group. The 19 values highlighted by Schwartz focus on: a) personal or social benefit of the result; $b$ ) growth and self-development or avoiding anxiety and protection; c) openness to change or maintaining the status quo; and d) focus on one's own benefit or the benefit of others. This technique contains 57 questions that allow us to assess the importance of 19 values:

$$
\begin{aligned}
& \text { - Security - Personal } \\
& \text { - Security - Public } \\
& \text { - Reputation } \\
& \text { - Universalism - Caring for others } \\
& \text { - Universalism - Caring for nature } \\
& \text { - Universalism - Tolerance } \\
& \text { - Independence - Thoughts } \\
& \text { - Independence - Acts } \\
& \text { - Power - Resources } \\
& \text { - Power - Domination } \\
& \text { - Conformism - Rules } \\
& \text { - Conformism - Interpersonal }
\end{aligned}
$$

\author{
- Modesty \\ - Benevolence - Sense of duty \\ - Benevolence - Caring \\ - Stimulation \\ - Hedonism \\ - Achievement \\ - Tradition
}

Each of the values in the methodology is measured by three points. This is the minimum required for conducting a confirmatory factor analysis that controls random and nonrandom measurement errors. Each question describes the goals of the individual, and expectations or desires that latently indicate the importance of a particular value. For each such portrait, the respondent determines how much the person described is similar to him on a six-point scale: 1 - not at all like me, 2 - not like me, 3 - not much like me, 4 - a little like me, 5 - like me, and 6 - is very similar to me. All respondents participating in our study received the appropriate language and gender versions of the questionnaire, which differed only in grammatical structure.

\subsection{Statistical Analysis}

The study used Qualtrics software, which allows online research, which in turn saves time for collecting information. In our study, 58 respondents answered online. The main methods for quantitative and qualitative data processing were the Alpha Cronbach coefficient, multivariate analysis of variance (MANOVA), Pearson correlation coefficient [21], Reliability, Missing data (SPSS), and descriptive statistics (tables, graphic imaging, and average value) [22].

\section{RESULTS}

The results of descriptive statistics for the Schwarz questionnaire are presented in (Table $\mathbf{1}$ and Fig. (1)), in which we clearly see that of the 19 indicators measured by this methodology, Kazakhstani subjects have the highest indicators on the following scales:

\footnotetext{
- Reputation scale (5.04),

- Benevolence - Sense of Duty scale (5.07),

- The Benevolence - Care scale (5.11), see Fig. (1).
}

Table 1. Descriptive statistics of the S. Schwartz values questionnaire.

\begin{tabular}{|c|c|c|c|c|}
\hline Scales & Min & Max & Avg. & Std. dev. \\
\hline 1 & 2 & 3 & 4 & 5 \\
\hline Independence - Thoughts & 2 & 6 & 4,93 & 0,75 \\
\hline Independence - Actions & 1 & 6 & 4,84 & 0,894 \\
\hline Hedonism & 1 & 6 & 4,48 & 0,925 \\
\hline Stimulation & 1 & 6 & 4,3 & 0,844 \\
\hline Achievement & 2 & 6 & 4,65 & 0,965 \\
\hline Power - Domination & 1 & 6 & 3,48 & 1,203 \\
\hline Power - Resources & 1 & 6 & 3,67 & 1,133 \\
\hline Reputation & 1 & 6 & 5,04 & 0,791 \\
\hline
\end{tabular}


(Table 1) contd.....

\begin{tabular}{|c|c|c|c|c|}
\hline Scales & Min & Max & Avg. & Std. dev. \\
\hline Social Security & 1 & 6 & 4,8 & 0,925 \\
\hline Tradition & 1 & 6 & 4,31 & 1,132 \\
\hline Conformity - Rules & 1 & 6 & 4,04 & 1,059 \\
\hline Conformity - Interpersonal & 1 & 6 & 4,24 & 0,978 \\
\hline Modesty & 1 & 6 & 4,32 & 0,925 \\
\hline Universalism - Caring for Nature & 1 & 6 & 4,06 & 1,036 \\
\hline Universalism - Caring for Others & 1 & 6 & 4,6 & 0,971 \\
\hline Universalism-Tolerance & 1 & 6 & 4,22 & 0,999 \\
\hline Benevolence-Care & 1 & 6 & 5,11 & 0,845 \\
\hline Benevolence - Sense of Duty & 1 & 6 & 5,07 & 0,938 \\
\hline
\end{tabular}

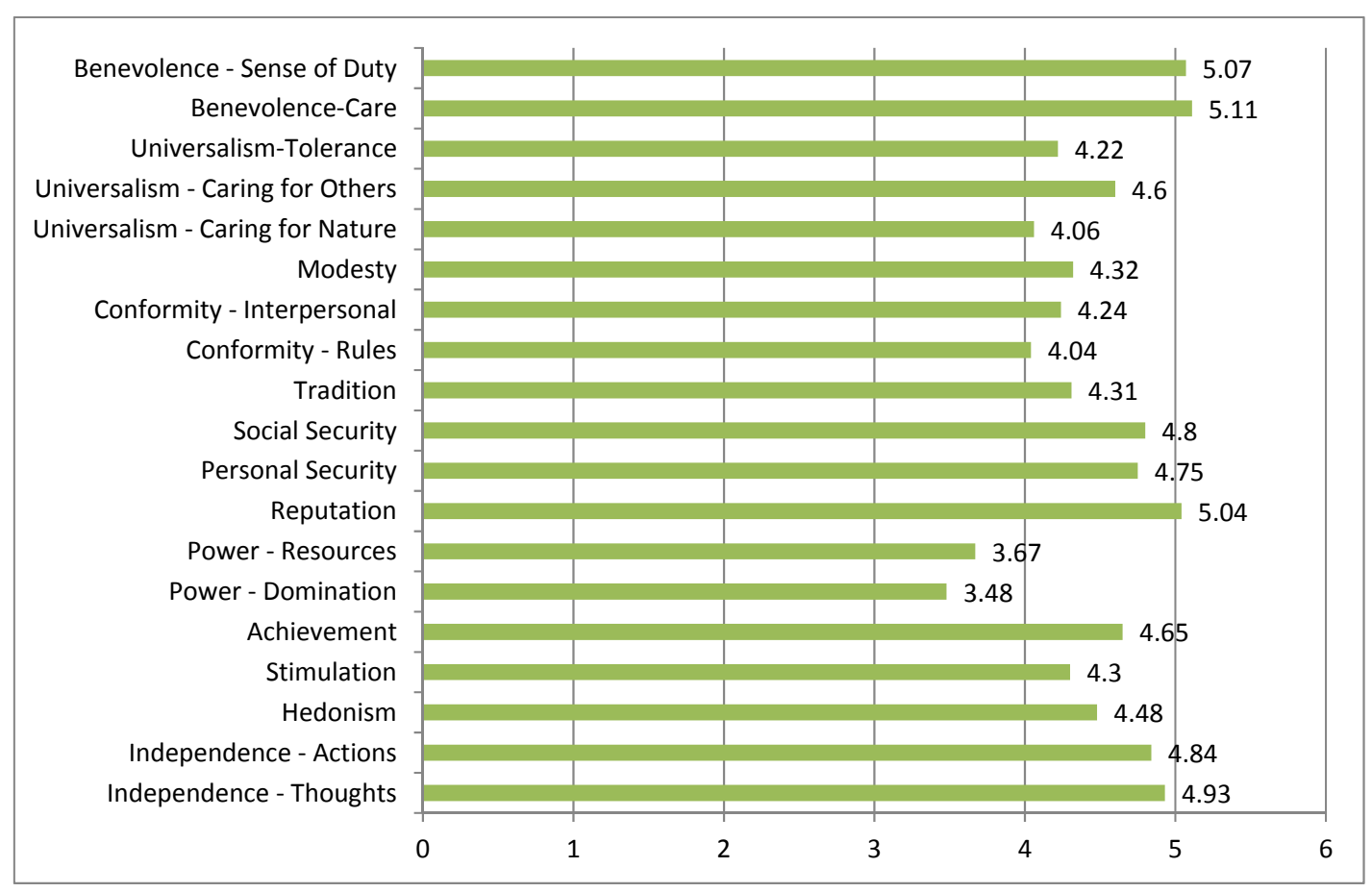

Fig. (1). Descriptive statistics of the S. Schwartz values questionnaire.

The smallest indicators are identified on such scales as:

Power - Domination (3.48),

Power - Resources (3.67).

These results indicate the specificity of the Kazakhstani mentality - an expression of benevolence not only in emotions, but also in specific actions such as care. These indicators suggest that the collectivistic type of culture is characteristic of Kazakhstan - the desire to be a reliable member of the group, and dedication to group members. These values relate to selfdetermination and social focus. High Reputation scores indicate internal conflict since this is the opposite of the Benevolence scale. High scores on this scale indicate pronounced tendencies to protect and influence by maintaining a public image and avoiding humiliation. This value relates to personal focus and avoiding anxiety. Therefore, we can say that dynamically changing social conditions cause an internal conflict between social and personal focus. This conflict is primarily caused by the manifestation of the cultural syndrome "individualism-collectivism", as a result of which Kazakhstani become vivid representatives of the collectivist culture, where predominant common interests of the group and devotion to it regulate the behavior of each member of the group; at the same time to achieve success, and self-actualize, they are forced to show distinct features relevant to individualistic cultures.

Low results of the value of Power indicate the absence of mechanisms of influence, which indicates the tension between the personal focus and the value of self-affirmation.

Table 2 and Fig. (2) show the results of descriptive statistics for the Schwartz values questionnaire for each separate group. 


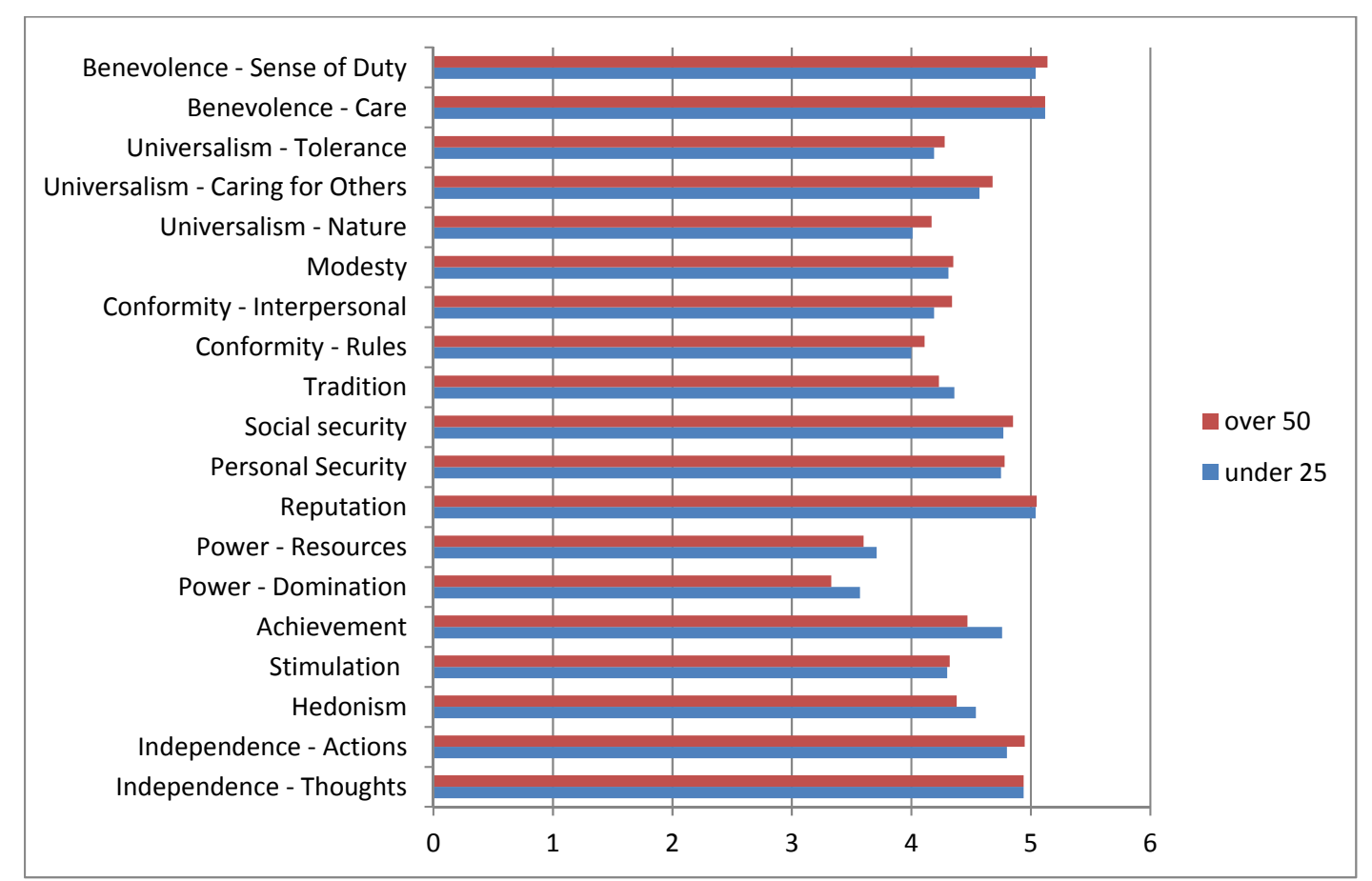

Fig. (2). Descriptive statistics of the Schwartz values questionnaire for two groups.

Table 2. Descriptive statistics of the Schwartz values questionnaire for two groups.

\begin{tabular}{|c|c|c|c|}
\hline Scales & Sample & Average & Std. Deviation \\
\hline 1 & 2 & 3 & 4 \\
\hline \multirow[t]{2}{*}{ Independence - Thoughts } & under 25 & 4,94 & 0,877 \\
\hline & over 50 & 4,94 & 0,813 \\
\hline \multirow[t]{2}{*}{ Independence - Actions } & under 25 & 4,80 & 0,877 \\
\hline & over 50 & 4,95 & 0,927 \\
\hline \multirow[t]{2}{*}{ Hedonism } & under 25 & 4,54 & 0,871 \\
\hline & over 50 & 4,38 & 1,02 \\
\hline \multirow[t]{2}{*}{ Stimulation } & under 25 & 4,30 & 0,805 \\
\hline & over 50 & 4,32 & 0,896 \\
\hline \multirow[t]{2}{*}{ Achievement } & under 25 & 4,76 & 0,929 \\
\hline & over 50 & 4,47 & 1,06 \\
\hline \multirow[t]{2}{*}{ Power - Domination } & under 25 & 3,57 & 1,16 \\
\hline & over 50 & 3,33 & 1,28 \\
\hline \multirow[t]{2}{*}{ Power - Resources } & under 25 & 3,71 & 1,09 \\
\hline & over 50 & 3,60 & 1,21 \\
\hline \multirow[t]{2}{*}{ Reputation } & under 25 & 5,04 & 0,806 \\
\hline & over 50 & 5,05 & 0,770 \\
\hline \multirow[t]{2}{*}{ Personal Security } & under 25 & 4,75 & 0,846 \\
\hline & over 50 & 4,78 & 0,810 \\
\hline \multirow[t]{2}{*}{ Social security } & under 25 & 4,77 & 0,872 \\
\hline & over 50 & 4,85 & 1,03 \\
\hline \multirow[t]{2}{*}{ Tradition } & under 25 & 4,36 & 1,11 \\
\hline & over 50 & 4,23 & 1,15 \\
\hline \multirow[t]{2}{*}{ Conformity - Personal } & under 25 & 4,00 & 1,08 \\
\hline & over 50 & 4,11 & 1,16 \\
\hline \multirow[t]{2}{*}{ Conformity - Interpersonal } & under 25 & 4,19 & 0,958 \\
\hline & over 50 & 4,34 & 1,02 \\
\hline
\end{tabular}


(Table 2) contd.....

\begin{tabular}{|c|c|c|c|}
\hline Scales & Sample & Average & Std. Deviation \\
\hline \multirow[t]{2}{*}{ Modesty } & under 25 & 4,30 & 0,939 \\
\hline & over 50 & 4,35 & 0,913 \\
\hline \multirow[t]{2}{*}{ Universalism - Nature } & under 25 & 4,01 & 1,07 \\
\hline & over 50 & 4,17 & 0,969 \\
\hline \multirow[t]{2}{*}{ Universalism - Caring for Others } & under 25 & 4,57 & 1,02 \\
\hline & over 50 & 4,68 & 0,856 \\
\hline \multirow[t]{2}{*}{ Universalism - Tolerance } & under 25 & 4,19 & 0,985 \\
\hline & over 50 & 4,28 & 1,04 \\
\hline \multirow[t]{2}{*}{ Benevolence - Care } & under 25 & 5,12 & 0,873 \\
\hline & over 50 & 5,12 & 0,771 \\
\hline \multirow[t]{2}{*}{ Benevolence - Sense of Duty } & under 25 & 5,04 & 1,01 \\
\hline & over 50 & 5,14 & 0,737 \\
\hline
\end{tabular}

According to the data presented in Table 2 and Fig. (2), it can be seen that the young and older generations have the same dominant and ignored value orientations. The dominant value orientations of the older and younger generation include:

- Personal Security (5.05 and 5.04),

- The Benevolence - Sense of Duty scale (5.14 and 5.04),

- Benevolence - Care scale (5.12 and 5.12).

Ignored Value Orientations:

- Power - Domination (3.33 and 3.71),

- Power - Resources (3.6 and 3.71).

The dominance of Personal Security among values indicates that personal focus is not completely displaced out of the minds of Kazakhstanis. The value orientations of Kazakhstan people, both young and older, are realized through mechanisms of growth and development, and self-defense. Whereas the mechanism of implementing value orientations avoiding anxiety, is used less often. Perhaps this is because the significance of the group and its inclusion in it allow us to cope with anxiety states quite successfully. Thus, in the system of value orientations of Kazakhstanis, an internal conflict is traced between personal and social focus, and between selfdetermination and self-affirmation. This trend can be explained by the processes of globalization and individualization, which have an impact on Kazakhstani society, which belongs to a highly collective culture. Globalization, on the one hand, contributes to the expansion of interconnection with other cultures, strengthens intercultural communication, provides an exchange of cultural heritage and experience, and brings to bear beneficial effect on Kazakhstani society as a whole; on the other hand, it leads to the gradual depletion of cultural syndromes, many national traditions, and values inherent to highly collectivist society. In particular, today, such centuriesold Kazakh customs and traditions, which made it possible to survive in nomadism, such as a high degree of hospitality, reverence for elders, providing group assistance to a relative in trouble, worshiping a man, etc., are losing their significance.

Individualization, like globalization, also leads to a change in the behavioral model of many Kazakhstani, especially youth. Many young Kazakhstani today strive for independence and autonomy, their own success and self-realization, and for the manifestation of a high degree of masculinity. This gradually leads to the rupture of friendly and family ties, which is especially painful for the Kazakhstani society built on tribal relations, tribalism, and a high power distance.

\subsection{Analysis of Variance}

The multiple analysis of variance (MANOVA) was applied on the Kazakhstani sample by the method of studying the value orientations of S. Schwartz. Key MANOVA indicators include one-dimensional and multidimensional criteria. As multidimensional criteria, multidimensional tests are used that take into account the correlation of dependent variables. These criteria, as well as their significance levels, are calculated for each factor and all interactions. One-dimensional criteria are the usual F-relations for testing hypotheses about the influence of factors and their interaction on each of the dependent variables separately. One-dimensional criteria make it possible to investigate those effects whose statistical significance is confirmed by multidimensional criteria. The results obtained include detailed descriptions of statistics (Table 3 ), the results of multidimensional tests (Table 4), and the assessment of the effects of one-dimensional tests (Tables 5-6).

\section{Table 3. Descriptive statistics.}

\begin{tabular}{|c|c|c|c|}
\hline \multicolumn{2}{|c|}{ Independent variables } & Samples & Quantity \\
\hline \multirow{2}{*}{ Age } & 1 & Under 25 & 202 \\
\cline { 2 - 4 } & 2 & Over 50 & 103 \\
\hline \multirow{2}{*}{ Gender } & 1 & Women & 194 \\
\cline { 2 - 4 } & 2 & Men & 111 \\
\hline
\end{tabular}

Table 4. The result of multidimensional tests.

\begin{tabular}{|c|c|c|c|c|c|c|c|}
\hline \multicolumn{2}{|c|}{ Indicators } & Values & $\mathbf{F}$ & $\begin{array}{c}\text { Hypothesis } \\
\text { variance }\end{array}$ & $\begin{array}{c}\text { Error } \\
\text { variance }\end{array}$ & Val. & $\begin{array}{c}\text { Partial } \\
\text { Eta-square }\end{array}$ \\
\hline Age & $\begin{array}{c}\text { Wilks' } \\
\lambda\end{array}$ & 0,907 & 1,526 & 19,000 & 283,000 & 0,076 & 0,093 \\
\hline $\begin{array}{c}\text { Gender } \\
\begin{array}{c}\text { Wilks' } \\
\lambda\end{array}\end{array}$ & 0,890 & 1,841 & 19,000 & 283,000 & 0,019 & 0,110 \\
\hline
\end{tabular}

As we can see in Table 4, Wilks' $\lambda=0.907, \mathrm{~F}=1.526$, and $\mathrm{p}=0.076$, which indicate that the dispersion-covariance matrices do not significantly differ in age. This means that the main assumption is fulfilled for multivariate tests, and their results can be accepted for consideration. The level of confidence is not critical; it indicates a tendency to differences. 
A detailed study with a larger sample and greater coverage of the regions of the Republic of Kazakhstan is therefore required. From Table 5, which presents the results of one-dimensional tests, it can be observed that generations (young people under 25 years and mature people over 50 years) are differentiated by only one value - the values of Achievement: $F=5.104, p$ $<0.025$, and partial Eta-square $=0.017$. The data in Table 2 indicate that this value is more formed among the younger generation - youth $(\mathrm{M}=4.74)$ and the older generation $(\mathrm{M}=$ 4.47).

Table 5. Evaluation of the effects of intergroup factors (variable age).

\begin{tabular}{|c|c|c|c|c|c|c|c|}
\hline Scales & Type III Square Sums & Variance & Mean Square & $\mathbf{F}$ & Val. & Partial Eta-square & - \\
\hline 1 & 2 & 3 & 4 & 5 & 6 & 7 & 8 \\
\hline \multirow[t]{2}{*}{ Age } & Independence - Thoughts & 0,002 & 1 & 0,002 & 0,003 & 0,957 & 0,000 \\
\hline & Independence - Actions & 1,021 & 1 & 1,021 & 1,276 & 0,260 & 0,004 \\
\hline & Hedonism & 1,059 & 1 & 1,059 & 1,229 & 0,268 & 0,004 \\
\hline & Stimulation & 0,112 & 1 & 0,112 & 0,164 & 0,686 & 0,001 \\
\hline & Achievement & 4,669 & 1 & 4,669 & 5,104 & 0,025 & 0,017 \\
\hline & Power - Domination & 3,063 & 1 & 3,063 & 2,100 & 0,148 & 0,007 \\
\hline & Power - Resources & 0,432 & 1 & 0,432 & 0,333 & 0,564 & 0,001 \\
\hline & Reputation & 0,243 & 1 & 0,243 & 0,395 & 0,530 & 0,001 \\
\hline & Personal security & 0,571 & 1 & 0,571 & 0,856 & 0,355 & 0,003 \\
\hline & Social security & 0,715 & 1 & 0,715 & 0,832 & 0,363 & 0,003 \\
\hline & Tradition & 0,023 & 1 & 0,023 & 0,019 & 0,891 & 0,000 \\
\hline & Conformity - Rules & 1,567 & 1 & 1,567 & 1,410 & 0,236 & 0,005 \\
\hline & Conformity - Interpersonal & 2,878 & 1 & 2,878 & 3,014 & 0,084 & 0,010 \\
\hline & Modesty & 0,956 & 1 & 0,956 & 1,158 & 0,283 & 0,004 \\
\hline & Universalism - Caring for nature & 1,320 & 1 & 1,320 & 1,221 & 0,270 & 0,004 \\
\hline & Universalism - Caring for others & 1,863 & 1 & 1,863 & 2,013 & 0,157 & 0,007 \\
\hline & Universalism - Tolerance & 0,340 & 1 & 0,340 & 0,349 & 0,555 & 0,001 \\
\hline & Benevolence - Care & 0,028 & 1 & 0,028 & 0,041 & 0,840 & 0,000 \\
\hline & Benevolence - Sense of Duty & 0,670 & 1 & 0,670 & 0,784 & 0,377 & 0,003 \\
\hline
\end{tabular}

Table 6. Estimates of 2 samples by age.

\begin{tabular}{|c|c|c|c|c|c|}
\hline \multirow[t]{2}{*}{ Dependent Variable } & \multirow[t]{2}{*}{ Sample } & \multirow[t]{2}{*}{ Mean } & \multirow[t]{2}{*}{ Std. Error } & \multicolumn{2}{|c|}{$95 \%$ confidential interval } \\
\hline & & & & Low bound & High bound \\
\hline 1 & 2 & 3 & 4 & 5 & 6 \\
\hline \multirow[t]{2}{*}{ Independence - Thoughts } & under 25 & 4,930 &, 055 & 4,822 & 5,038 \\
\hline & over 50 & 4,925 & ,077 & 4,773 & 5,077 \\
\hline \multirow[t]{2}{*}{ Independence - Actions } & under 25 & 4,792 &, 065 & 4,663 & 4,920 \\
\hline & over 50 & 4,919 & 092 & 4,738 & 5,100 \\
\hline \multirow[t]{2}{*}{ Hedonism } & under 25 & 4,524 & ,068 & 4,390 & 4,657 \\
\hline & over 50 & 4,394 &, 095 & 4,206 & 4,582 \\
\hline \multirow[t]{2}{*}{ Stimulation } & under 25 & 4,293 & ,060 & 4,175 & 4,412 \\
\hline & over 50 & 4,251 & ,085 & 4,084 & 4,418 \\
\hline \multirow[t]{2}{*}{ Achievement } & under 25 & 4,741 &, 070 & 4,604 & 4,878 \\
\hline & over 50 & 4,469 & ,098 & 4,275 & 4,662 \\
\hline \multirow[t]{2}{*}{ Power - Domination } & under 25 & 3,576 & ,088 & 3,403 & 3,750 \\
\hline & over 50 & 3,356 & ,124 & 3,112 & 3,600 \\
\hline \multirow[t]{2}{*}{ Power - Resources } & under 25 & 3,706 & ,083 & 3,542 & 3,870 \\
\hline & over 50 & 3,623 &, 117 & 3,393 & 3,853 \\
\hline \multirow[t]{2}{*}{ Reputation } & under 25 & 4,997 & ,057 & 4,884 & 5,110 \\
\hline & over 50 & 5,059 & ,081 & 4,901 & 5,218 \\
\hline \multirow[t]{2}{*}{ Personal security } & under 25 & 4,695 & ,060 & 4,577 & 4,812 \\
\hline & over 50 & 4,790 & ,084 & 4,625 & 4,955 \\
\hline \multirow[t]{2}{*}{ Social security } & under 25 & 4,744 & ,068 & 4,610 & 4,877 \\
\hline & over 50 & 4,850 & , 095 & 4,663 & 5,038 \\
\hline
\end{tabular}


(Table 6) contd.....

\begin{tabular}{|c|c|c|c|c|c|}
\hline \multirow[t]{2}{*}{ Dependent Variable } & \multirow[t]{2}{*}{ Sample } & \multirow[t]{2}{*}{ Mean } & \multirow[t]{2}{*}{ Std. Error } & \multicolumn{2}{|c|}{$95 \%$ confidential interval } \\
\hline & & & & Low bound & High bound \\
\hline \multirow[t]{2}{*}{ Tradition } & under 25 & 4,303 &, 081 & 4,143 & 4,463 \\
\hline & over 50 & 4,284 & ,114 & 4,059 & 4,509 \\
\hline \multirow[t]{2}{*}{ Conformity - Rules } & under 25 & 3,950 & 077 & 3,799 & 4,102 \\
\hline & over 50 & 4,108 & , 108 & 3,895 & 4,321 \\
\hline \multirow[t]{2}{*}{ Conformity - Interpersonal } & under 25 & 4,157 & 071 & 4,017 & 4,298 \\
\hline & over 50 & 4,371 & 100 & 4,174 & 4,569 \\
\hline \multirow[t]{2}{*}{ Modesty } & under 25 & 4,232 & ,066 & 4,102 & 4,363 \\
\hline & over 50 & 4,356 & ,093 & 4,172 & 4,539 \\
\hline \multirow[t]{2}{*}{ Universalism - Caring for nature } & under 25 & 4,004 & ,076 & 3,855 & 4,153 \\
\hline & over 50 & 4,149 & , 107 & 3,939 & 4,359 \\
\hline \multirow[t]{2}{*}{ Universalism - Caring for others } & under 25 & 4,512 &, 070 & 4,374 & 4,650 \\
\hline & over 50 & 4,684 & 099 & 4,489 & 4,878 \\
\hline \multirow[t]{2}{*}{ Universalism - Tolerance } & under 25 & 4,145 & ,072 & 4,004 & 4,287 \\
\hline & over 50 & 4,219 & 101 & 4,019 & 4,418 \\
\hline \multirow[t]{2}{*}{ Benevolence - Care } & under 25 & 5,077 &, 061 & 4,957 & 5,196 \\
\hline & over 50 & 5,098 &, 085 & 4,930 & 5,266 \\
\hline \multirow[t]{2}{*}{ Benevolence - Sense of Duty } & under 25 & 5,003 & ,067 & 4,870 & 5,136 \\
\hline & over 50 & 5,106 & 095 & 4,919 & 5,293 \\
\hline
\end{tabular}

\section{DISCUSSION}

The study showed that Kazakhstani youth is more focused on achieving success in accordance with social standards. This conclusion is logical and corresponds to the age characteristics of the sample. The values that unite two generations are also revealed:

- Independence - Thoughts

- Independence - Actions

- Hedonism

- Stimulation

- Power - Domination

- Power - Resources

- Reputation

- Personal Security

- Social security

- Tradition

- Conformity - Rules

- Conformity - Interpersonal

- Modesty

- Universalism - Care for nature

- Universalism - Caring for Others

- Universalism - Tolerance

- Benevolence - Care

- Benevolence - Sense of Duty

The study of value orientations by gender, reflected in Table 7 and Fig. (3), shows that the system of value orientations of men and women is differentiated by the following 6 values:
- Stimulation $(\mathrm{p}=0.002, \mathrm{~F}=9.676)$;

- Personal security $(\mathrm{p}=0.031, \mathrm{~F}=4.702)$;

- Modesty $(\mathrm{p}=0.013, \mathrm{~F}=6.247)$;

- Universalism-Tolerance ( $\mathrm{p}=0,000, \mathrm{~F}=12,691)$;

- Benevolence-Care $(\mathrm{p}=0.012, \mathrm{~F}=6.404)$;

- Benevolence-Sense of duty $(\mathrm{p}=0.010, \mathrm{~F}=6.773)$.

The indicators presented in Table 7 and Fig. (3) indicate that this group of values is better formed in women.

Consequently, women are comparatively more oriented toward the pursuit of novelty and change, the safety of their immediate environment, the recognition of the insignificance of one person's life cycle, the acceptance and understanding of those who are different from you, the dedication to the group and the well-being of its members and the desire to be a reliable and worthy trust group member than men. Most of the values correspond to the traditional female role; the exception is the value of Stimulation, which indicates the transformation of social representations of the traditional female role. Note that the differences relate to the three meta-values of Self Determination, Self - Preservation, and Openness to Change.

The study identified 13 value orientations that combine both sexes:

- Independence - Thoughts

- Independence - Acts

- Hedonism

- Achievement

- Power dominance

- Power Resources

- Reputation

- Social Security 
- Tradition

- Conformity rules

- Interpersonal conformity

- Universalism - Caring for nature

- Universalism - Caring for others

As we can see, men and women equally aim at developing abilities and ideas, with the freedom to determine their own actions, the desire for success, and the desire to exert influence through control. The revealed similarities and differences in the system of values of men and women indicate the presence of transformational processes associated with a change in ideas about traditionally male and female roles. Thus, the dominant value orientations of the older and younger generation were: Personal Security (5.05 and 5.04), Benevolence - Sense of Duty (5.14 and 5.04), and Benevolence - Care (5.12 and 5, 12). Ignored value orientations: Power - Dominance (3.33 and 3.71) and Power - Resources (3.6 and 3.71).

Table 7. Estimates of 2 samples by gender.

\begin{tabular}{|c|c|c|c|c|c|}
\hline \multirow[t]{2}{*}{ Dependent Variable } & \multirow[t]{2}{*}{ Sample } & \multirow[t]{2}{*}{ Mean } & \multirow[t]{2}{*}{ Std. Error } & \multicolumn{2}{|c|}{ 95\% Confidential Interval } \\
\hline & & & & Low Bound & High Bound \\
\hline 1 & 2 & 3 & 4 & 5 & 6 \\
\hline \multirow[t]{2}{*}{ Independence - Thoughts } & women & 4,987 & ,057 & 4,874 & 5,099 \\
\hline & men & 4,868 &, 076 & 4,719 & 5,017 \\
\hline \multirow[t]{2}{*}{ Independence - Actions } & women & 4,936 & ,068 & 4,803 & 5,070 \\
\hline & men & 4,775 &, 090 & 4,598 & 4,952 \\
\hline \multirow[t]{2}{*}{ Hedonism } & women & 4,488 & 070 & 4,349 & 4,626 \\
\hline & men & 4,430 &, 093 & 4,246 & 4,614 \\
\hline \multirow[t]{2}{*}{ Stimulation } & women & 4,434 & ,063 & 4,311 & 4,557 \\
\hline & men & 4,110 & ,083 & 3,947 & 4,274 \\
\hline \multirow[t]{2}{*}{ Achievement } & women & 4,669 & 072 & 4,527 & 4,812 \\
\hline & men & 4,541 & ,096 & 4,351 & 4,730 \\
\hline \multirow[t]{2}{*}{ Power - Domination } & women & 3,428 & ,092 & 3,248 & 3,609 \\
\hline & men & 3,503 &, 122 & 3,264 & 3,743 \\
\hline \multirow[t]{2}{*}{ Power - Resources } & women & 3,656 & ,086 & 3,486 & 3,826 \\
\hline & men & 3,673 &, 115 & 3,448 & 3,899 \\
\hline \multirow[t]{2}{*}{ Reputation } & women & 5,115 & 059 & 4,998 & 5,232 \\
\hline & men & 4,941 & 079 & 4,786 & 5,097 \\
\hline \multirow[t]{2}{*}{ Personal security } & women & 4,854 & ,062 & 4,732 & 4,975 \\
\hline & men & 4,631 & ,082 & 4,469 & 4,792 \\
\hline \multirow[t]{2}{*}{ Social security } & women & 4,863 & 070 & 4,725 & 5,001 \\
\hline & men & 4,731 & ,093 & 4,547 & 4,915 \\
\hline \multirow[t]{2}{*}{ Tradition } & women & 4,331 &, 084 & 4,165 & 4,498 \\
\hline & men & 4,256 &, 112 & 4,035 & 4,476 \\
\hline \multirow[t]{2}{*}{ Conformity - Rules } & women & 4,146 &, 080 & 3,989 & 4,304 \\
\hline & men & 3,912 & , 106 & 3,703 & 4,121 \\
\hline \multirow[t]{2}{*}{ Conformity - Interpersonal } & women & 4,285 & 074 & 4,140 & 4,431 \\
\hline & men & 4,243 & ,098 & 4,050 & 4,437 \\
\hline \multirow[t]{2}{*}{ Modesty } & women & 4,437 & 069 & 4,302 & 4,572 \\
\hline & men & 4,151 & ,091 & 3,971 & 4,331 \\
\hline \multirow[t]{2}{*}{ Universalism - Caring for nature } & women & 4,156 & 079 & 4,001 & 4,311 \\
\hline & men & 3,997 &, 105 & 3,791 & 4,203 \\
\hline \multirow[t]{2}{*}{ Universalism - Caring for others } & women & 4,712 & 073 & 4,569 & 4,856 \\
\hline & men & 4,483 & ,097 & 4,292 & 4,674 \\
\hline \multirow[t]{2}{*}{ Universalism - Tolerance } & women & 4,404 & 075 & 4,256 & 4,551 \\
\hline & men & 3,961 & ,099 & 3,765 & 4,156 \\
\hline \multirow[t]{2}{*}{ Benevolence - Care } & women & 5,220 & ,063 & 5,096 & 5,344 \\
\hline & men & 4,955 &, 084 & 4,790 & 5,119 \\
\hline \multirow[t]{2}{*}{ Benevolence - Sense of Duty } & women & 5,206 & 070 & 5,068 & 5,344 \\
\hline & men & 4,903 & ,093 & 4,720 & 5,086 \\
\hline
\end{tabular}




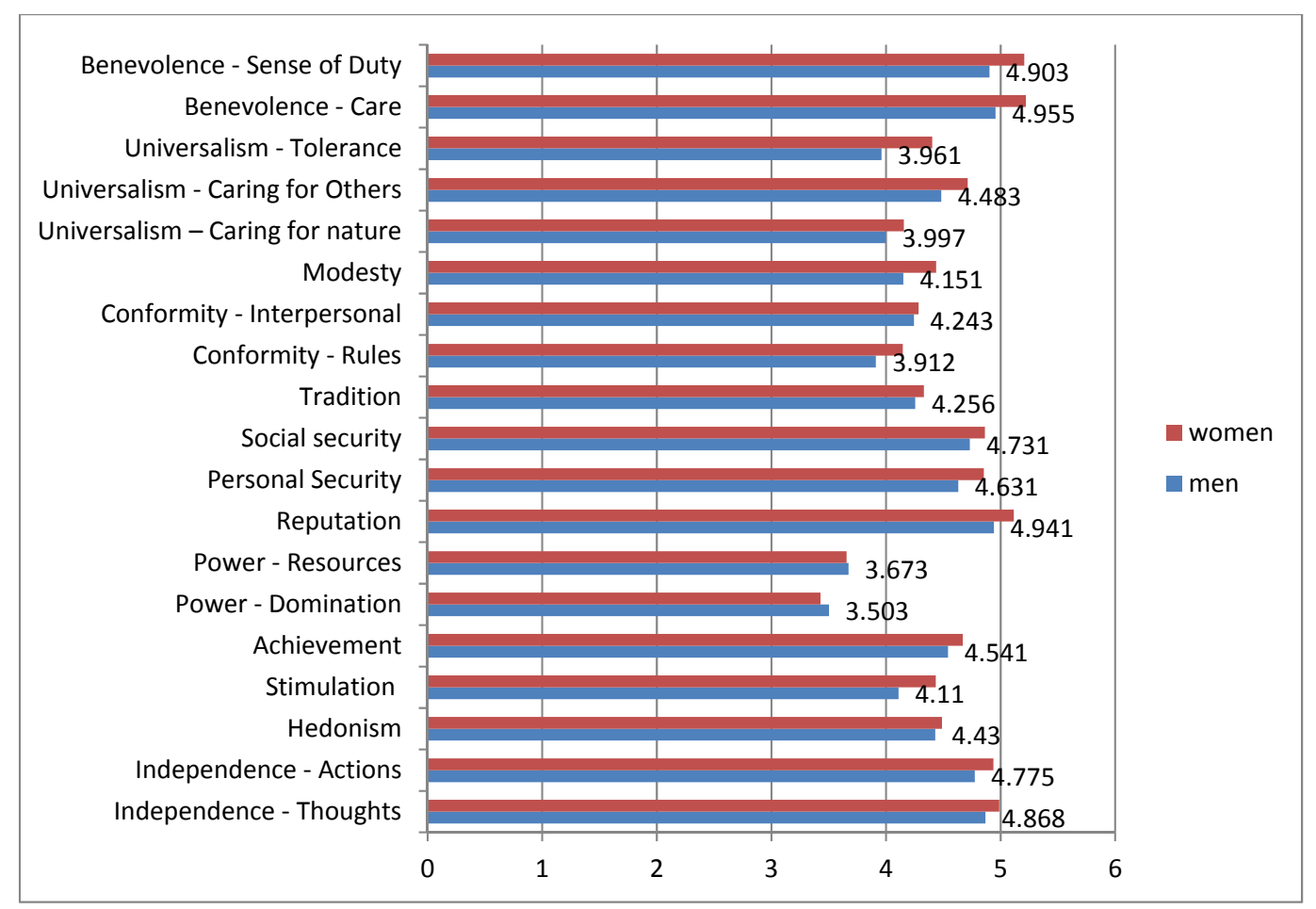

Fig. (3). Estimates of 2 samples by gender.

In the system of value orientations of Kazakhstanis, an internal conflict can be identified between personal and social focus, and between self-determination and self-affirmation. The following values differentiate between the two generations: the value of Achievement, Social complexity, and Control of fate. The two genders are differentiated by values such as Social cynicism, Control of fate, Stimulation, Personal Security, Modesty, Universalism - Tolerance, Benevolence Care, and Benevolence - Sense of duty.

\section{CONCLUSION}

We conducted an empirical study based on the understanding of values as the most important component of the personality structure, which has a dual character, connecting the inner world and the surrounding reality, and manifested in a selective attitude to the surrounding reality, to other people, and to ourselves. In accordance with the purpose and hypothesis of the study, value orientations were experimentally studied using the Schwarz values questionnaire. The authors' modification and adaptation of modern technologies for the study of value orientations made it possible to provide an objective description of the basic values of the personality of Kazakhstanis. It was objectively revealed that despite the deep transformations of Kazakhstani society, the value orientations of modern Kazakhstanis tend to preserve the basic value component, which is a mechanism of the transfer of sustainable elements of the value system from generation to generation. The value orientations characteristic of a highly collectivist culture are of common nature in different generations. The value orientations of Kazakhstan people, both young and older, are realized through mechanisms of growth and development, and self-defense. During the experimental study, it was found that the main factors determining the formation of value orientations are age, gender, and general socio-economic factors, as well as the moral and spiritual formation of a modern personality to a large extent determined by beliefs in which basic value orientations hold a central role. The results of this study are of great importance for the young state as a reflection of the relations that have developed between the generation brought up in the spirit of the ideas of socialism and communism and the young generation that has formed in the post-Soviet society with the ideals and values that are characteristic of countries with market economies. The experimentally established features of value orientations will make it possible to predict and optimize the ways of formation and development of basic values and personal beliefs.

\section{THEORETICAL AND PRACTICAL IMPLICATIONS}

The identification and study of the values of various social and gender groups allow us to identify significant trends in the change of value orientations in general and also serve as a key to understanding the direction of both general social development and its individual sides. The study of the value orientations of modern youth is of theoretical and practical importance since it makes it possible to find out the degree of its adaptation to the new social, political, and economic conditions of post-Soviet Kazakhstan. The future state of society largely depends on what value foundation will be formed among the young generation. In this regard, the development of the spiritual and socio-cultural potential of the country is one of the strategic directions of the Republic of Kazakhstan, which allows forming a system of fundamental basic values and beliefs through the national idea of public policy aimed at educating "creative" leaders, and competitive, self-sufficient specialists [23]. 


\section{LIMITATIONS}

One of the limitations of the study is that it covered only the study of the value orientations of students. In the future, we expect that Kazakhstani youth belonging to different social strata will be the focus. Another limitation of the study is the imbalance between the samples, as in one group, students were more dominant in number than representatives of the mature generation. Thus, in future studies, it is very important to maintain the same number of participants for all research sample groups. Given the country's multinationality, and its multiculturalism, another limitation is that the study was conducted without taking nationality into account. Subsequent studies should focus on value orientations based on nationality, national stereotypes, and prejudices.

\section{ETHICS APPROVAL AND CONSENT TO PARTI- CIPATE}

The study was approved by the Al-Farabi Kazakh National University, Kazakhstan under ethical approval number 2710/4 IRB00010790.

\section{HUMAN AND ANIMAL RIGHTS}

No Animals were used in this research. All human research procedures followed were in accordance with the ethical standards of the committee responsible for human experimentation (institutional and national), and with the Helsinki Declaration of 1975, as revised in 2013.

\section{CONSENT FOR PUBLICATION}

Informed consent was taken from all the participants when they were enrolled.

\section{AVAILABILITY OF DATA AND MATERIALS}

The authors confirm that the data supporting the findings of this study are available within the article.

\section{FUNDING}

None.

\section{CONFLICT OF INTEREST}

The authors declare no conflict of interest, financial or otherwise.

\section{ACKNOWLEDGEMENTS}

The research team would like to express sincere gratitude to higher education institutions that participated in the study.

\section{REFERENCES}

[1] Ageeva AV. Value orientations of russian youth. Materials of the Lomonosov readings 2003; $2: 21$.

[2] Ikhsanova DT, Aymaganbetov AB. Socio-psychological characteristics of the development of value orientations in adolescence. Bulletin of Kazakh National University. al-Farabi. Series of Psychology and Sociology 2013; 2: 23-33.

[3] Kurilenko YuA. The semantic sphere as a structural element of personality. Psychopedagogy in law enforcement agencies 2014; 2 : 20-3.

[4] Craig G. Developmental psychology Trans. English St. Petersburg: Peter 2000 .
[5] Lange A, Frankl V. Attorney for humanity. Psychol Issues 2005; 3: 107-11.

[6] Rokeach M. The nature of human values. N.Y.: Free Press 1973; p. 75

[7] Musek Y. The value system of post-communist Europe in during transition period. Foreign psychology 1997; 8: 17-22.

[8] Schwartz SH. Universals in the content and structure of values: Theoretical advances and empirical tests in 20 countries.Advances in Experimental Social PsychologyOrlando, FL: Academic 1992; 25: pp. $1-65$.

[http://dx.doi.org/10.1016/S0065-2601(08)60281-6]

[9] Schwartz SH, Butenko TP, Sedova DS, Lipatova AS. Refined theory of basic individual values: Application in Russia. Psychology. J Higher School Eco 2012; 1: 43-70.

[http://dx.doi.org/10.1007/978-3-319-56352-7 3]

[10] Schleder B. The structure of value orientations. Empirical research Foreign psychology 1994; 20: 47-56.

[11] Leontiev DA. Value representations in individual and group consciousness: Types, determinants and changes in time. Psychol Rev 1998; (1): 13-25.

[12] Leontiev DA. Psychology of meaning: Nature, structure and dynamics of semantic reality M. Meaning 1999; p. 53.

[13] Ananiev BG. About issues of modern human knowledge. St. Petersburg: Peter 2001; p. 272.

[14] Khachatryan MA. Values and attributive processes in social cognition. Social psychology and society $2014 ; 1: 84-97$.

[15] Bogdan SI. Psychological factors of the formation of value orientations of the personality (on the example of student youth of Kazakhstan). Candidate of Science diss Department of Psychology, Novosibirsk State University 2008.

[16] Ikhsanova DT, Aymaganbetov AB. Cross-cultural study of students' value orientations. Bulletin of Kazakh National University. al-Farabi. Series of Psychology and Sociology 2014; 1: 68-77.

[17] Kassymova L. Psychological aspects of the value orientations of Kazakhstani youth. Candidate of Science diss Department of Psychology, Kazakh National University al-Farabi. 2015.

[18] Kassymova LS, Aimaganbetova OKh, Yermekbaeva MK. An examination of values and social beliefs of Kazakhstani youth. Bulletin of Kazakh National University al-Farabi. Series of Psychology and Sociology 2014; 2(49): 3-13.

[19] Vygotsky LS, Luria AP. Studies on the history of behavior: Ape, primitve, and child holisdate. N.J.: Erlbaum 1993.

[20] Cole M. Studying behavior in context: A mesogenetic approach // Cultural-Historical Psychology 2015; 11(4): 55-68.

[21] Nasledov AD. Mathematical methods of psychological research Analysis and interpretation data SPb. Speech 2012

[22] Nasledov AD. IBM SPSS, Statistics 20, and AMOS: Professional Statistical Data Analysis SPb. Peter 2013.

[23] Alzhanova LS, Aymaganbetova OKh, Ermekbaev MK. Formation of a national idea through value orientations of personality. In: Materials of the "Peace Science" international conference of young scientists dedicated to the 20th anniversary of the state symbols of the Republic of Kazakhstan Almaty. 2012; pp. 42-5.

[24] Kudryashov AF. Technique "Value orientations of M Rokich" The best psychological tests for professional selection and career guidance. Petrozavodsk: Petrocom 1992; p. 114.

[25] Leontyev DA. Methodology for the study of value orientations 1992; 176.

[26] Leontiev DA. From social to personal values: sociogenesis and value phenomenology regulation of personality. Bulletin of Moscow State University, "Psychology. Series 1996; 4: 42.

[27] Smirnov LM. A typology of basic values based on unconscious comparisons. Psychol Issues 2006; 6: 120-31.

[28] Shadrin NA. Psychology: Personal Values Pavlodar: Pavlodar State University na S. Toraigyrov 2003.

[29] Shakeeva C. Value orientations and well-being of young people in new social economic conditions. Voronezh: Publishing house of NPO MODEK 1998; p. 192.

[30] Schwartz SH, Bilsky W. Towards psychological structure of human values. J Pers Soc Psychol 1987; 550-62.

[http://dx.doi.org/10.1037/0022-3514.53.3.550]

[31] Schwartz SH, Melech G, Lehmann A, Burgess S, Harris M. Extending the cross-cultural validity of the theory of basic human values with a different method of measurement. J Cross Cult Psychol 2001; 32 [http://dx.doi.org/10.1177/0022022101032005001]

[32] Sheveleva A. Values of professional sphere in youth subcultures. Open Psychol J 2020; 13: 27-39.https://benthamopen.com/TOPSYJ/ VOLUME/13/ 
[http://dx.doi.org/10.2174/1874350102013010027]

[33] Alrajhi M, Aldhafri S, Alkharusi H, Alharthy I, Albarashdi H,

Alhadabi A. Grade and Gender Effects on Self-Concept Development.
Open Psychol J 2019; 12: 66-75.https://benthamopen.com/TOPSYJ/ VOLUME/12/

[http://dx.doi.org/10.2174/1874350101912010066]

\section{C) 2021 Adilova et al.}

This is an open access article distributed under the terms of the Creative Commons Attribution 4.0 International Public License (CC-BY 4.0), a copy of which is available at: https://creativecommons.org/licenses/by/4.0/legalcode. This license permits unrestricted use, distribution, and reproduction in any medium, provided the original author and source are credited. 